\title{
ANALISIS PERHITUNGAN PENYUSUTAN ASET TETAP MENURUT \\ PSAK 17 DAN UNDANG-UNDANG PAJAK SERTA DAMPAKNYA \\ TERHADAP PENGHASILAN KENA PAJAK PADA PT.WANA ARTA \\ MANUNGGAL
}

\author{
Leroy Lionel Yuhaniar \\ Universitas Buddhi Dharma \\ leroylionel62@yahoo.co.id
}

\begin{abstract}
This study aims to determine how the calculation of depreciation of fixed assets in accordance with IAS 17 and the Law - Tax Law as well as determine the impact on taxable income of both of these calculations. In this study the author uses descriptive method is a method of analyzing the data which the data are collected, compiled, interpreted, and analyzed so as to produce a complete information and efficient in accordance with the title analysis of calculation of depreciation of fixed assets according to IAS 17 and law - tax law and its impact taxable income at PT Wana Manunggal Arta ". The data collected is primary and secondary data. Using a variety of data collection techniques, such as interview techniques, observation techniques. The author has analyzed the fixed assets of the company and it can be concluded that the company put on straight-line depreciation method to depreciate its fixed assets has been well implemented by the company. Application of the method of depreciation for tax purposes in accordance with the provisions of the tax is less because there are weaknesses in its application. Depreciation expense based on commercial Rp 197,323,566 whereas according to the fiscal depreciation expense amounting to $R p$ 169,967,624 was due to differences in the method of depreciation according to tax provisions contained fiscal correction of the vehicles used for the company's operations and for the inventory of vehicles for employees.
\end{abstract}

Keywords: Fixed Assets, Depreciation of Fixed Assets According to IAS 17 LawTax Law, Taxable Income.

\section{PENDAHULUAN}

Menurut PSAK No. 17 istilah penyusutan berarti pengalokasian jumlah suatu aset yang dapat disusutkan sepanjang masa manfaat yang diestimasi. Besarnya penyusutan untuk periode akuntansi dibebankan ke pendapatan baik secara langsung maupun tidak langsung. Kesalahan dalam penetapan metode penyusutan dan penggunaan asset tetap dapat 
mempengaruhi rencana perusahaan dalam mencapai tujuannya. Kesalahan dalam ukuran aset tetap juga dapat mempengaruhi kewajaran laporan keuangan secara signifikan terutama terhadap penyusutan. Kesalahan tersebut dapat dihindari dengan cara menentukan taksiran umur ekonomis aset tetap dan metode penyusutan yang digunakan. Dengan adanya daftar aset tetap, maka informasi mengenai jumlah, jenis, nilai akan mudah di dapat. Hal ini tidak akan saja memudahkan perhitungan laba dan penghasilan kena pajak perusahaan tetapi juga memudahkan kegiatan pengawasan aset tetap perusahaan. Untuk itu dituntut penerapan penyusutan akuntansi aset tetap yang baik sebagai media informasi untuk pihak manajemen dalam mengoptimalkan

\section{TELAAH LITERATUR}

Menurut Agoes dan Estralita Trisnawati (2010) mengatakan bahwa akuntansi adalah sistem yang menghasilkan laporan kepada pihakpihak yang berkepentingan mengenai aktivitas ekonomi dan kondisi perusahaan. Menurut Waluyo (2011) menyatakan bahwa akuntansi pajak penggunaan aset tetap perusahaan. Sebab dalam penetapan tujuan perusahaan semua aspek harus diperhatikan termasuk penyusutan aset tetap. Berdasarkan uraian diatas jelaslah bahwa pentingnya cara menghitung penyusutan aset tetap menurut PSAK No. 17 dan undangundang pajak yang berlaku di Indonesia, membatasi permasalahan pada perhitungan aset tetap mesin pada PT. Wana Arta Manunggal, maka penulis tertarik untuk mengadakan penelitian sebagai dalam bentuk skripsi dengan judul analisis perhitungan penyusutan aset tetap menurut PSAK No. 17 dan undang-undang pajak serta dampaknya terhadap penghasilan kena pajak pada PT. Wana Arta Manunggal.

adalah akuntansi yang berkaitan dengan perhitungan perpajakan dan mengacu pada perarturan dan perundang-undang perpajakan beserta aturan pelaksanaannya. Tujuan akuntansi berdasarkan PSAK adalah menyediakan informasi yang menyangkut posisi keuangan, kinerja serta perubahan posisi keuangan 
suatu perusahaan yang bermanfaat bagi sejumlah besar pengguna laporan keuangan dalam pengambilan keputusan ekonomi. Menurut Waluyo (2009) menyatakan bahwa aset tetap adalah aset berwujud yang diperoleh dalam bentuk siap pakai atau dengan dibangun terlebih dahulu, yang digunakan dalam operasi perusahaan, tidak dimaksudkan untuk dijual dalam rangka kegiatan normal perusahaan dan mempunyai masa manfaat lebih dari satu tahun (PSAK No. 16 Tahun 2007). Sedangkan menurut Hery dan Widyawati (2011) mengatakan bahwa aset tetap adalah aset yang di mana secara fisik dapat dilihat keberadaannya dan sifatnya relative permanen serta memiliki masa kegunaan yang panjang. Jenis aset tetap yang berwujud yang dimiliki oleh suatu perusahaan bisa berupa: tanah, bangunan, mesin dan alat - alat pabrik, meubel, dan alat alat kantor, kendaraan dan alat - alat kantor dan sebagainya. Menurut Kieso (2011) menyatakan bahwa menetapkan nilai perolehan aset tetap sebagai berikut :
Termasuk dalam nilai perolehan tanah antara lain :

1. Purchase price; harga yang dibayarkan kepada penjual

2. Closing costs ; biaya hukum, biaya pengurusan surat - surat

3. Costs incurred in getting the land in condition for its intended use ; seperti perataan, pembuatan drainase dan pembersihan

4. Pelunasan biaya - biaya yang masih harus dibayar seperti pajak bumi dan bangunan, dan lain - lain

5. Perbaikan tanah lainnya, seperti perbaikan jalan, pagar, tempat parker, dan lain - lain

Sedangkan yang termasuk dalam nilai perolehan gedung antara lain semua pengeluaran yang berhubungan langsung dengan proses perolehannya ataupun konstruksinya, seperti bahan baku, tenaga kerja, biaya overhead selama konstruksi. nilai perolehan peralatan antara lain seperti harga yang dibayarkan 
kepada penjual, biaya transportasi, biaya asuransi dalam perjalanan, biaya komisi, jika ada, biaya pemasangan, biaya uji coba penggunaan. Menurut Steven M. Bragg (2012) mengatakan bahwa biaya-biaya yang termasuk dalam properti, pabrik, dan peralatan, harga pembelian dari aset dan pajak yang terkait, biaya konstruksi dari aset, yang mencakup biaya buruh dan imbalan pekerja, bea impor, biaya pengangkutan dan penanganan, persiapan lokasi, instalasi dan perakitan, permulaan uji coba asset, biaya operasional, biaya yang diestimasi untuk membongkar dan menghapus aset tersebut selanjutnya, jika ini adalah sebuah keharusan, pengurangan diskon dan potongan harga, pengurangan penerimaan bersih dari penjualan setiap produk yang dihasilkan selama pengujian awal. Masalah penyusutan merupakan masalah yang penting selama masa manfaat aset tetap. Masa manfaat diukur dengan periode suatu aset yang diharapkan digunakan perusahaan atau jumlah produksi atau unit serupa yang diharapkan diperoleh dari aset oleh perusahaan.
Jumlah Penyusutan akan dialokasikan ke setiap periode akuntansi selama masa manfaat aset tetap berwujud menggunakan berbagai metode yang sistematis. Menurut Sugiri (2009) mengatakan bahwa penyusutan adalah alokasi sistematis jumlah yang dapat disusutkan dari suatu aset selama umur manfaatnya. Menurut Donald Kieso (2009) menyatakan bahwa penyusutan adalah proses akuntansi dalam mengalokasikan biaya aset berwujud ke beban dengan cara yang sistematis dan rasional selama periode yang diharapkan mendapatkan manfaat dari penggunaan aset tersebut.

Metode penyusutan menurut ketentuan perundang-undangan perpajakan sebagaimana telah diatur dalam Pasal 11 undang-undang Pajak Penghasilan antara lain sebagai berikut adalah :

1. metode garis lurus ( straight line method ), atau metode saldo menurun (declining balance method ) untuk aset tetap berwujud bukan bangunan.

2. metode garis lurus untuk aset tetap berwujud berupa bangunan. 


\begin{tabular}{|c|c|c|}
\hline Kriteria & Akuntansi Komersial & Akuntansi Fiskal \\
\hline $\begin{array}{c}\text { Masa } \\
\text { Manfaat }\end{array}$ & $\begin{array}{l}\text { 1. Ditentukan } \\
\text { berdasarkan umur } \\
\text { ekonomis maupun } \\
\text { teknis. }\end{array}$ & $\begin{array}{ll}\text { 1. Diterapkan } & \\
\text { berdasarkan } & \\
\text { keputusan } & \text { Menteri } \\
\text { Keuangan. } & \end{array}$ \\
\hline & $\begin{array}{l}\text { 2. Nilai residu } \\
\text { diperhitungkan. } \\
\text { 3. Ditelaah ulang } \\
\text { secara periodik. }\end{array}$ & $\begin{array}{l}\text { 2. Nilai residu tidak } \\
\text { diperhitungkan. }\end{array}$ \\
\hline & $\begin{array}{l}\text { 1. Untuk pembelian } \\
\text { menggunakan harga } \\
\text { sesungguhnya. }\end{array}$ & $\begin{array}{l}\text { 1. Untuk transaksi yang } \\
\text { tidak memiliki } \\
\text { hubungan istimewa }\end{array}$ \\
\hline $\begin{array}{l}\text { Harga } \\
\text { Perolehan }\end{array}$ & $\begin{array}{l}\text { 2. Untuk pertukaran } \\
\text { menggunakan harga }\end{array}$ & $\begin{array}{l}\text { berdasarkan harga } \\
\text { sesungguhnya. }\end{array}$ \\
\hline & $\begin{array}{l}\text { 3. Untuk pertukaran } \\
\text { aset sejenis } \\
\text { berdasarkan nilai } \\
\text { buku aset yang } \\
\text { dilepas. } \\
\text { 4. Untuk sumbangan } \\
\text { berdasarkan harga } \\
\text { pasar. }\end{array}$ & $\begin{array}{l}\text { memiliki hubungan } \\
\text { istimewa berdasarkan } \\
\text { harga pasar. } \\
\text { 3. Untuk transaksi tukar } \\
\text { menukar berdasarkan } \\
\text { harga pasar. }\end{array}$ \\
\hline $\begin{array}{c}\text { Metode } \\
\text { Penyusutan }\end{array}$ & $\begin{array}{l}\text { 1. Wajib pajak } \\
\text { diijinkan memilih } \\
\text { salah satu metode } \\
\text { yang sesuai asalkan } \\
\text { dilaksanakan secara }\end{array}$ & $\begin{array}{l}\text { 1. Untuk aset tetap } \\
\text { bangunan adalah } \\
\text { garis lurus dengan } \\
\text { persentase yang telah } \\
\text { ditetapkan. }\end{array}$ \\
\hline & $\begin{array}{lr}\text { kontinyu, } & \text { antara } \\
\text { lain metode } & \text { garis } \\
\text { lurus, } & \text { saldo } \\
\text { menurun } & \text { saldo } \\
\text { menurun } & \text { ganda, } \\
\text { angka } & \text { tahun, } \\
\text { produksi, dll. } & \end{array}$ & $\begin{array}{l}\text { 2. Untuk aset tetap } \\
\text { bukan bangunan } \\
\text { boleh memilih antara } \\
\text { garis lurus maupun } \\
\text { saldo menurun } \\
\text { asalkan dilaksanakan } \\
\text { secara konsisten. }\end{array}$ \\
\hline \multirow{4}{*}{$\begin{array}{l}\text { Sistem } \\
\text { Penyusutan }\end{array}$} & $\begin{array}{lr}\text { 1. } & \text { Penyusutan } \\
\text { individual, kecara } \\
\text { peralatan } & \text { kecil }\end{array}$ & $\begin{array}{l}\text { 1. Penyusutan } \\
\text { individual dan } \\
\text { gabungan / group. }\end{array}$ \\
\hline & $\begin{array}{l}\text { boleh } \\
\text { golongan. }\end{array}$ & $\begin{array}{l}\text { 2. Saat dimulainya } \\
\text { penyusutan adalah }\end{array}$ \\
\hline & $\begin{array}{l}\text { 2. Saat dimulainya } \\
\text { penyusutan adalah }\end{array}$ & $\begin{array}{l}\text { saat perolehan atau } \\
\text { saat menghasilkan }\end{array}$ \\
\hline & $\begin{array}{l}\text { saat perolehan } \\
\text { maupun } \\
\text { penyelesaian }\end{array}$ & $\begin{array}{l}\text { atas ijin Menteri } \\
\text { Keuangan }\end{array}$ \\
\hline
\end{tabular}


Penghasilan Kena Pajak

Penghasilan kena pajak atau laba fiscal (taxable profit) atau rugi pajak (tax loss) adalah laba atau rugi selama satu periode yang dihitung berdasarkan perarturan perpajakan dan yang menjadi dasar perhitungan pajak penghasilan. Beban pajak penghasilan ini terdiri atas beban pajak kini (dalam tahun berjalan) dan

\section{METODE PENELITIAN}

Objek penelitian yang dilakukan penulis adalah penyusutan aset tetap menurut PSAK No. 17 dan undang undangpajak serta dampaknya terhadap penghasilan kena pajak pada PT. Wana Arta Manunggal. Dalam penelitian ini penulis menggunakan metode deskriptif, di mana data-data yang dikumpulkan adalah semua data yang digunakan mengenai aset tetap PT. Wana Arta Manunggal baik yang dipakai secara langsung pada pengelolaan data dan pengumpulan fakta-fakta lain yang secara tidak langsung membantu mencapai tujuan penulisan skripsi ini. Tipe penelitian yang digunakan didalam penelitian ini adalah tipe penelitian yang bertujuan untuk beban pajak penghasilan. PSAK 46 memberikan istilah yang perlu dipahami di mana beban pajak ( $\operatorname{tax}$ expense) adalah jumlah agregat pajak kini (current tax) dan pajak tangguhan (deferred tax) yang diperhitungkan dalam penghasilan laba rugi akuntansi pada suatu atau dalam periode berjalan sebagai beban atau penghasilan.

menemukan pengetahuan khusus maupun tentang suatu peristiwa nilai yang tidak wajar dalam laporan keuangan dibandingkan dengan nilai aset tersebut di pasaran. Penelitian ini juga di didasarkan pada peraturan-peraturan perpajakan dan juga standar akuntansi keuangannya (SAK) agar tidak terjadi penyimpangan antara perusahaan dan pemerintah. Data-data yang digunakan adalah data primer dan data sekunder. Teknik pengumpulan data yang digunakan oleh penulis adalah dengan menggunakan penelitian kepustakaan dan penelitian lapangan di mana penelitian yang dilakukan secara langsung kepada objek penelitian untuk melengkapi data yang 
dibutuhkan. Penelitian ini dilakukan dengan meneliti secara langsung keperusahaan untuk mendapatkan data yang sekunder yang akurat dan penelitian ini dilakukan dengan beberapa tindakan, yaitu : wawancara (interview), dokumentasi,

HASIL PENELITIAN DAN PEMBAHASAN

Beban penyusutan aset tetap pada PT. Wana Arta Manunggal dihitung dengan menggunakan metode garis lurus untuk penyusutan komersil dan penyusutan fiskal untuk aset tetap

Tabel 1 Perhitungan Beban Penyusutan Aset Tetap Menurut Komersial

\begin{tabular}{clcccc} 
No & Keterangan & $\begin{array}{c}\text { Umur } \\
(\text { Thn })\end{array}$ & $\begin{array}{c}\text { Rate } \\
(\%)\end{array}$ & $\begin{array}{c}\text { Harga } \\
\text { Perolehan }\end{array}$ & $\begin{array}{c}\text { Beban } \\
\text { Penyusutan }\end{array}$ \\
& Inventaris & 4 & 25 & 97.037 .536 & 18.129 .003 \\
1 & Kantor & 4 & 25 & 721.262 .400 & 97.711 .883 \\
2 & Kendaraan & 4 & 25 & 403.653 .136 & 81.482 .680 \\
3 & Mesin - Mesin & TOTAL & & & $\mathbf{1 9 7 . 3 2 3 . 5 6 6}$ \\
\hline
\end{tabular}

Tabel 2 Perhitungan Beban Penyusutan Aset Tetap Menurut Fiskal

\begin{tabular}{clccccc} 
No & Keterangan & Kel & $\begin{array}{c}\text { Umur } \\
(\text { Thn })\end{array}$ & $\begin{array}{c}\text { Tarif } \\
(\%)\end{array}$ & $\begin{array}{c}\text { Harga } \\
\text { Perolehan }\end{array}$ & $\begin{array}{c}\text { Beban } \\
\text { Penyusutan }\end{array}$ \\
1 & $\begin{array}{l}\text { Inventaris } \\
\text { Kantor }\end{array}$ & I & 4 & 25 & 97.037 .536 & 18.129 .003 \\
2 & Kendaraan & II & 4 & 25 & 721.262 .400 & 70.355 .941 \\
3 & $\begin{array}{l}\text { Mesin - Mesin } \\
\text { TOTAL }\end{array}$ & III & 4 & 25 & 403.653 .136 & 81.482 .680 \\
& & & & & $\mathbf{1 6 9 . 9 6 7 . 6 2 4}$ \\
\hline
\end{tabular}


Dari rincian tersebut dapat diperoleh informasi di mana beban penyusutan untuk periode tahun 2013 berdasarkan akuntansi keuangan adalah sebesar $\mathrm{Rp}$ 197.323.566. Beban penyusutan untuk periode tahun 2013 berdasarkan ketentuan perpajakan adalah sebesar $\mathrm{Rp}$ 169.967.624. Selisih antara penyusutan menurut akuntansi keuangan dengan ketentuan perpajakan adalah sebesar $\mathrm{Rp}$ 27.355.942. Jadi jumlah ini yang akan direkonsiliasi, di mana penyusutan menurut komersil lebih besar dari penyusutan fiskal sehingga selisih ini bersifat koreksi positif yaitu akan menambah besarnya penghasilan kena pajak perusahaan. Selisih dari kedua perhitungan tersebut disebabkan karena metode penyusutan aset tetap menurut ketentuan perpajakan berdasarkan Kep Dirjen No. 220/PJ/2002, SE09/PJ.42/2002 tentang kendaraan sedan / sejenis atas biaya perolehan / pembelian / perbaikan besar kendaraan sedan / sejenis yang dimiliki \& dipergunakan perusahaan untuk pegawai tertentu karena jabatan / pekerjaannya, dapat dibebankan sebagai biaya perusahaan sebesar 50\% melalui penyusutan aset tetap kelompok II, atau biaya pemeliharaan / perbaikan rutin kendaraan tersebut dapat dibebankan sebagai biaya rutin perusahaan sebesar $50 \%$. Adanya perbedaanperbedaan signifikan antara perarturan perpajakan dengan standar akuntansi keuangan bisa menjadikan laba kena pajak berbeda dan selanjutnya menyebabkan perbedaan dasar penetapan pajak penghasilan terutang. Apabila pihak manajemen tidak teliti dalam mengantisipasi perbedaan tersebut, maka penetapan pengenaan pajak penghasilan terutang akan berbeda antara jumlah yang dicantumkan dalam SPT Tahunan dengan pemeriksaan yang dilakukan oleh pihak pajak dan selanjutnya apabila itu terjadi perusahaan akan dikenakan denda atau sanksi administrasi yang akan merugikan perusahaan bersangkutan. Tidak selamanya dengan melakukan koreksi fiskal laba akuntansi akan menjadi lebih kecil dibandingkan laba fiskal. Apabila laba fiskal lebih besar maka penetapan pajaknya pun akan lebih besar. Hal ini disebabkan 
adanya biaya-biaya yang diakui dalam laporan keuangan komersial yang memang merupakan pengeluaran, namun bukan merupakan biaya menurut ketentuan perpajakan. Berdasarkan penelitian yang dilakukan dapat diketahui bahwa untuk menentukan besarnya laba kena pajak, perusahaan melakukan rekonsiliasi fiskal untuk menghitung besarnya pajak yang terutang sehingga pada akhirnya nanti diperoleh besarnya laba setelah pajak. Analisa yang dilakukan atas koreksi fiskal yang dibuat oleh perusahaan adalah bahwa perusahaan telah melakukan koreksi fiskal dengan baik ditinjau dari segi teknik atau cara perusahaan melakukan koreksi terhadap laba akuntansi sebelum pajak, yaitu dengan melakukan koreksi positif. Koreksi positif dilakukan apabila ada beban, dalam hal ini beban penyusutan aset tetap diakui dalam laporan keuangan komersial, tetapi tidak diakui sebagai beban atau pengurang penghasilan menurut ketentuan perpajakan. Koreksi yang dilakukan yaitu dengan mengurangkan sejumlah beban dari beban penyusutan hal ini akan menambah laba akuntansi sebelum pajak. Namun koreksi yang dilakukan perusahaan masih terdapat kelemahan yaitu adanya kesalahan dalam menghitung besarnya beban penyusutan fiskal sehingga selisih jumlah beban penyusutan yang akan ditambahkan kembali ke laba akuntansi sebelum pajak akan mencerminkan jumlah yang sebenarnya. Hal ini disebabkan kelemahan dalam penerapan undangundang perpajakan seperti yang telah diuraikan sebelumnya sehingga terjadi kekeliruan dalam menghitung beban penyusutan fiskal. Dalam penyajian laporan keuangan beban pajak penghasilan akan disajikan dalam perhitungan laba rugi dan merupakan jumlah antara pajak penghasilan terutang serta pajak yang ditangguhkan. Sementara dalam neraca kewajiban pajak yang ditangguhkan akan dilaporkan sebagai pos tidak lancar (hutang lainlain) dan pajak penghasilan terutang dilaporkan sebagai hutang lancar. 


\section{KESIMPULAN}

Setelah memberikan uraian mengenai masalah, menganalisa dan mengevaluasi akuntansi penyusutan aset tetap menurut SAK dan UndangUndang Perpajakan serta dampaknya terhadap penghasilan kena pajak pada PT Wana Arta Manunggal, maka penulis mencoba untuk menarik kesimpulan sekaligus memberikan saran - saran yang dapat diterapkan di perusahaan. Metode penyusutan yang diterapkan oleh perusahaan untuk tujuan pelaporan keuangan adalah metode garis lurus, sedangkan untuk tujuan perpajakan, di mana perusahaan menggunakan metode garis lurus untuk aset tetap bukan bangunan. Perusahaan telah melakukan koreksi fiskal atas laba akuntansi sebelum pajak untuk memperoleh laba kena pajak dan secara teknik koreksi tersebut telah dilakukan dengan baik. Perusahaan menghitung besarnya pajak penghasilan terutang berdasarkan laba kena pajak atau laba fiskal. Penyajian laporan keuangan berkaitan dengan perbedaan yang bersifat sementara kurang sesuai dengan Standar akuntansi keuangan karena perusahaan menerapkan metode bersih dari pajak, sedangkan standar akuntansi keuangan menganut metode aset-hutang dalam mengalokasikan jumlah yang dapat dikenakan pajak di masa depan karena perbedaan sementara. Karena perusahaan menggunakan metode bersih dari pajak, maka di neraca tidak ada akun kewajiban pajak yang ditangguhkan dan dalam laporan laba rugi, beban pajak penghasilan adalah sama dengan pajak penghasilan yang harus dibayar. Beban penyusutan menurut komersial sebesar $\mathrm{Rp}$ 197.323.566 sedangkan beban penyusutan menurut fiskal sebesar Rp 169.967.624 selisih dari kedua perhitungan tersebut karena metode penyusutan aset tetap menurut ketentuan perpajakan terdapat koreksi fiskal mengenai kendaraan yang dipakai untuk operasional perusahaan disusutkan sepenuhnya dari harga perolehan, sedangkan untuk kendaraan inventaris pegawai hanya dikenakan biaya 50\% dari tiap penyusutan per tahun. Besarnya efisiensi PPH terutang badan yang dihasilkan sebesar Rp 43.552.533 diperoleh dari rekonsiliasi fiskal yang dilakukan dari laba kena pajak 
sebagai dasar perhitungan pajak penghasilan. Penerapan metode penyusutan untuk tujuan perpajakan kurang sesuai dengan ketentuan perpajakan karena terdapat beberapa kelemahan dalam penerapannya yaitu perhitungan dasar penyusutan untuk tahun 2013 dalam sekelompok aset tertentu didasarkan pada harga perolehan aset dikurangi dengan akumulasi penyusutan sampai dengan tahun 2012 tanpa memperhitungkan adanya penjualan sejumlah aset tetap dari golongan aset tersebut pada periode sebelumnya. Pengelompokkan aset tetap bukan bangunan kurang sesuai dengan Keputusan Menteri Keuangan No.138/KMK.03/2002. Saran yang penulis berikan untuk perusahaan di mana sebaiknya mempertimbangkan penggunaan metode penyusutan lain yang sesuai dengan standar akuntasi keuangan. Karena metode garis lurus kurang tepat untuk aset yang mengalami

\section{DAFTAR PUSTAKA}

Sukrisno, A \& Trisnawati, E. (2010) Akuntansi Perpajakan Edisi 2 Revisi. Jakarta : Salemba Empat. penurunan kondisi. Di mana pada saat aset tersebut mengalami penurunan kondisi sehingga dikeluarkan biaya akan meningkat hal ini dilakukan untuk mempertahankan kinerja aset tersebut. Contohnya mesin yang digunakan perusahaan yang kinerjanya tidak mungkin tetap selama masa manfaat 15 tahun akan lebih baik jika disusutkan menurut metode jam kerja atau saldo menurun. Perusahaan sebaiknya mengkaji ulang kembali pengelompokkan aset tetapnya dan menyesuaikannya dengan keputusan Menteri Keuangan No. 138/KMK.03/2002 tentang pengelompokkan jenis-jenis harta berwujud. Pegawai perusahaan bagian perpajakan hendaknya harus memahami akan praktek administrasi perpajakan seperti penagihan dan teknik-teknik pemeriksaan pajak yang dilakukan oleh petugas perpajakan.

Anastasia, D \& Setiawati, L. (2010). Sistem Informasi Akuntansi. Yogyakarta:Andi Yogyakarta. 
Waluyo. (2011). Perpajakan

Indonesia. Jakarta : Salemba

Empat.

Waluyo. (2009). Akuntansi Pajak

Edisi Empat Buku 2. Jakarta

:Salemba Empat.

Ikatan Akuntan Indonesia. (2012).

Standar

Akuntansi

Keuangan. Jakarta : Ikatan

Akuntan Indonesia.

Dunia Firdaus A. (2010). Ikhtisar

Lengkap Pengantar

Akuntansi Edisi Ketiga.

Jakarta : Fakultas Ekonomi

Universitas Indonesia.

Giri Efraim Ferdinan. (2012).

Akuntansi Keungan

Menengah I. Jogjakarta :

UPP STIM YKPN.

Hery \& Widyawati Lekok. (2011).

Akuntansi Keuangan Menengah II. Jakarta : Bumi Aksara.

Kasmir. (2012). Analisis Laporan

Keuangan. Jakarta : PT Raja

Grafindo Persada.

Sugiri Slamet. (2009). Akuntansi

Suatu Pengantar 2 Edisi

Kelima. Jogjakarta : UPP STIM YKPN.

Kieso Donald. 2009. Intermediate

Accounting. Jakarta : Erlangga.

Bragg, Steven M. (2012). IFRS

Made Easy. Jakarta : Indeks.

Ikatan Akuntan Indonesia. 2009.

Pernyataan Standar Akuntan

Keuangan No. I, Revisi 2009. Dewan Standar Akuntansi Keuangan. Jakarta : Ikatan Akuntan Indonesia.

Kieso, Weygandt, Warfield. (2011).

Intermediate Accounting.

IFRS Edition. Hoboken :

New Jersey. 